This item was submitted to Loughborough's Research Repository by the author.

Items in Figshare are protected by copyright, with all rights reserved, unless otherwise indicated.

\title{
Glucose diffusivity of tissue engineering membranes and scaffolds
}

PLEASE CITE THE PUBLISHED VERSION

http://conferences.ncl.ac.uk/tces2014/conference/

\section{PUBLISHER}

(c) the authors

\section{VERSION}

VoR (Version of Record)

LICENCE

CC BY-NC-ND 4.0

\section{REPOSITORY RECORD}

Suhaimi, Hazwani, Shuai Wang, and Diganta Bhusan Das. 2014. "Glucose Diffusivity of Tissue Engineering Membranes and Scaffolds". figshare. https://hdl.handle.net/2134/15558. 
This item was submitted to Loughborough's Institutional Repository (https://dspace.lboro.ac.uk/) by the author and is made available under the following Creative Commons Licence conditions.

\section{creative
commons}

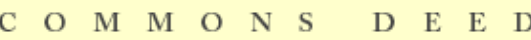

Attribution-NonCommercial-NoDerivs 2.5

You are free:

- to copy, distribute, display, and perform the work

Under the following conditions:

Attribution. You must attribute the work in the manner specified b the author or licensor.

Noncommercial. You may not use this work for commercial purposes.

No Derivative Works. You may not alter, transform, or build upon this work.

- For any reuse or distribution, you must make clear to others the license terms of this work.

- Any of these conditions can be waived if you get permission from the copyright holder.

Your fair use and other rights are in no way affected by the above.

This is a human-readable summary of the Leqal Code (the full license).

\section{Disclaimer 만}

For the full text of this licence, please go to: http://creativecommons.org/licenses/by-nc-nd/2.5/ 


\title{
Nutrient transport properties of tissue engineering membranes and scaffolds
}

\author{
Hazwani Suhaimi*, Shuai Wang and Diganta Bhusan Das
}

Department of Chemical Engineering, Loughborough University, UK

*Email: $\underline{\text { H.Suhaimi@lboro.ac.uk }}$

\section{INTRODUCTION:}

The idea of growing artificial tissues in bioreactors such as hollow fibre membrane bioreactors (HFMBs) has started some time ago and preparation of biocompatible porous membranes and scaffolds has been attempted extensively. There have also been a number of studies on modelling glucose transport processes in HFMB. However, there is little information available that discusses specifically the glucose diffusivity across tissue engineering membranes or scaffolds and, importantly, its dependence on the properties of the materials (i.e., membrane and, scaffold) ${ }^{1}$. In this study, we construct a simple diffusion cell to determine scale dependent glucose transport processes for a number of porous membranes and scaffolds of different pore size and shapes, saturated with water and cell culture media (CCM). Porosity and tortuosity of the used materials are determined and consequently correlated to the glucose diffusion coefficient values.

\section{METHODS:}

Five different membranes and scaffolds were employed, which include cellulose nitrate membrane (CN), polyvinylidene fluoride membrane (PVDF), poly(L-lactide) scaffold (PLLA), poly(caprolactone) scaffold (PCL) and collagen scaffold (see Table 1).

\section{Diffusion experiment:}

The diffusion cell consisted of two half chambers with identical volumes, namely donor and receptor phase. The membrane/scaffold was fixed in between. The donor phase was filled with glucose solution while the receptor phase contained pure water or CCM. The whole apparatus was placed in a thermostated water bath at either 27 or $37 \pm 1^{\circ} \mathrm{C}$. Samples were taken from both the donor and receptor phase at intervals of $1 \mathrm{~h}$ until equilibrium was established. A UV spectrophotometer was used to monitor the change in glucose concentration over time for materials saturated with water while an YSI glucose analyser was used for experiments in CCM.

\section{RESULTS:}

Data revealed an increase in the diffusion coefficient at a larger pore size, indicating least resistance of glucose molecules diffusing through the pores. Data also showed a significant reduction of glucose diffusion coefficient through materials saturated with CCM at a given temperature. For instance, the glucose diffusion coefficient of PVDF membrane was reduced from $1.87 \times 10^{-10} \mathrm{~m}^{2} / \mathrm{s}$ to $7.68 \times 10^{-11} \mathrm{~m}^{2} / \mathrm{s}$ when the membrane was saturated in water and $\mathrm{CCM}$ at $37^{\circ} \mathrm{C}$, respectively.

Table 1 Characteristics of the materials studied

\begin{tabular}{|c|c|c|}
\hline Material & Thickness $(\boldsymbol{\mu m})$ & Pore size $(\boldsymbol{\mu m})$ \\
\hline PVDF & 125 & 0.1 \\
\hline CN & 122.5 & 0.45 \\
\hline PLLA & 50 & $12-18$ \\
\hline
\end{tabular}

\begin{tabular}{|c|c|c|}
\hline PCL & 50 & $20-30$ \\
\hline Collagen & 1500 & 80 \\
\hline
\end{tabular}

\section{DISCUSSION \& CONCLUSIONS:}

In this study, the significance of the increase of diffusion coefficient with increasing pore size of the materials was derived. It was also observed that glucose diffusion coefficients through membrane and scaffold pores saturated with CCM are significantly reduced at a given temperature which is contrary to what have been assumed in the previous studies on glucose transport processes in HFMB or similar bioreactors.
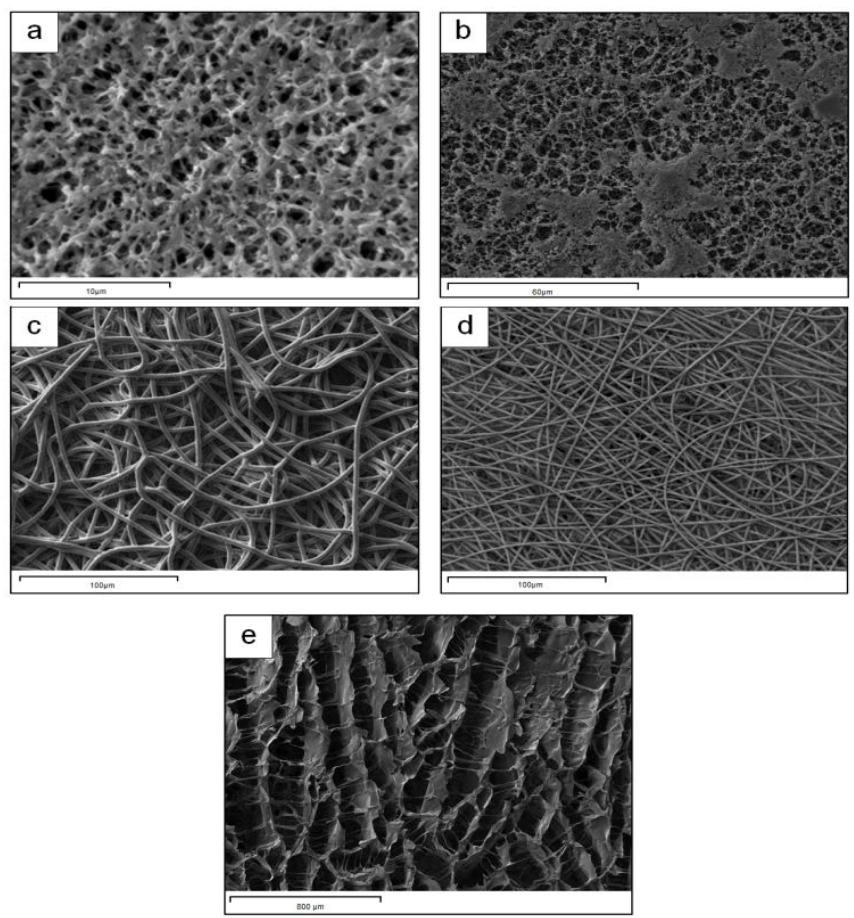

Fig. 1 SEM micrographs showing morphology of: (a) PVDF membrane, (b) CN membrane, (c) PCL scaffold, (d) PLLA scaffold and (e) Collagen scaffold

\section{REFERENCES:}

${ }^{1}$ Liu et al (2013), Journal of Tissue Engineering and Regenerative Medicine, DOI: 10.1002/term.1654

\section{ACKNOWLEDGMENTS:}

The authors gratefully acknowledge Brunei Government for funding this work. 